\title{
A digital rights management system based on a scalable blockchain
}

Garba, Abba; Dwivedi, Ashutosh Dhar; Kamal, Mohsin; Srivastava, Gautam; Tariq, Muhammad; Hasan, M. Anwar; Chen, Zhong

Published in:

Peer-to-Peer Networking and Applications

Link to article, DOI:

$10.1007 / \mathrm{s} 12083-020-01023-z$

Publication date:

2020

Document Version

Publisher's PDF, also known as Version of record

Link back to DTU Orbit

Citation (APA):

Garba, A., Dwivedi, A. D., Kamal, M., Srivastava, G., Tariq, M., Hasan, M. A., \& Chen, Z. (2020). A digital rights management system based on a scalable blockchain. Peer-to-Peer Networking and Applications, (Special Issue on Blockchain for Peer-to-Peer Computing). https://doi.org/10.1007/s12083-020-01023-z

\section{General rights}

Copyright and moral rights for the publications made accessible in the public portal are retained by the authors and/or other copyright owners and it is a condition of accessing publications that users recognise and abide by the legal requirements associated with these rights.

- Users may download and print one copy of any publication from the public portal for the purpose of private study or research.

- You may not further distribute the material or use it for any profit-making activity or commercial gain

- You may freely distribute the URL identifying the publication in the public portal 


\title{
Correction to: A digital rights management system based on a scalable blockchain
}

\author{
Abba Garba $^{1,2}$ - Ashutosh Dhar Dwivedi ${ }^{3}$ Mohsin Kamal $^{4} \cdot$ Gautam Srivastava $^{5,6}$ - Muhammad Tariq ${ }^{4,7}$. \\ M. Anwar Hasan ${ }^{8}$ - Zhong Chen ${ }^{1,2}$
}

(C) Springer Science+Business Media, LLC, part of Springer Nature 2021

\section{Correction to: Peer-to-Peer Netw Appl https://doi.org/10.1007/s12083-020-01023-Z}

In the original publication, the 3rd author Mohsin Kamal was mistakenly affiliated to Princeton University, Princeton, USA. The correct affiliation is presented in this Erratum.

Publisher's note Springer Nature remains neutral with regard to jurisdictional claims in published maps and institutional affiliations.

The online version of the original article can be found at https://doi.org/ 10.1007/s12083-020-01023-z

Gautam Srivastava

srivastavag@brandonu.ca

$\triangle$ Zhong Chen

zhongchen@pku.edu.cn

Abba Garba

abbaggumel@pku.edu.cn

Ashutosh Dhar Dwivedi

adhdw@dtu.dk

Mohsin Kamal

mohsin.kamal@nu.edu.pk

Muhammad Tariq

mtariq@princeton.edu

M. Anwar Hasan

ahasan@uwaterloo.ca
Key Laboratory of High Confidence Software Technologies, Peking University, MoE, Beijing, China

2 Department of Computer Science and Technology, EECS, Peking University, Beijing, China

3 Department of Applied Mathematics and Computer Science, Technical University of Denmark, Lyngby, Denmark

4 Department of Electrical Engineering, National University of Computer and Emerging Sciences, Peshawar, Pakistan

5 Department of Mathematics and Computer Science, Brandon University, Brandon, MB R7A 6A9, Canada

6 Research Center for Interneural Computing, China Medical University, Taichung 40402, Taiwan, Republic of China

7 Princeton University, Princeton, NJ, USA

8 Department of Electrical and Computer Engineering, University of Waterloo, Waterloo, ON, Canada 